\title{
NOVEL TARGETS FOR SUSTAINABLE CONTROL OF APPLE BLACKSPOT
}

\author{
R.W. CHYNOWETH ${ }^{1}$ and K.M. PLUMMER ${ }^{2}$ \\ ${ }^{1}$ HortResearch, Private Bag 92196, Auckland, New Zealand \\ ${ }^{2}$ University of Auckland, Private Bag 92019, Auckland, New Zealand \\ Corresponding author: kplummer@hortresearch.co.nz.
}

\begin{abstract}
A fungal peptide (from Saccharomyces cerevisiae - 'brewers yeast') has been shown to be an inhibitor of fungal infection structures in the apple pathogens Venturia inaequalis (black spot or scab) and Glomerella cingulata (the bitter rot pathogen) in in vitro studies. Crude yeast extract also inhibits infection structure formation, although possibly by a different process. Both peptide and yeast extract were investigated for activity against $V$. inaequalis spores during infection of leaves. The effect of the peptide and crude yeast preparations on ascospore production was also investigated. Preliminary trials showed these fungal products had a major impact, strongly inhibiting sexual reproduction of $V$. inaequalis in vitro. The effect was most dramatic with the crude yeast extract treatments, with pseudothecium and ascospore production virtually eliminated. The peptide alone also had a major effect in reducing sexual spore production of the fungus. The effect of yeast extracts and pure peptides on the development of pseudothecia is under further investigation.
\end{abstract}

\section{PRIMARY BIOASSAY FOR EVALUATING GLIOCLADIUM ISOLATES FOR BIOLOGICAL CONTROL OF BOTRYTIS CINEREA ON STRAWBERRY FLOWERS}

\section{S. CARD ${ }^{1}$, J.M PAY ${ }^{1}$, M.V. JASPERS ${ }^{1}$, M. WALTER ${ }^{2}$, A. STEWART ${ }^{1}$ and B. SNEH ${ }^{3}$}

\author{
${ }^{I}$ The National Centre for Advanced Bio-protection Technologies, P.O. Box 84, \\ Lincoln University, Canterbury, New Zealand \\ ${ }^{2}$ HortResearch, P.O. Box 51, Lincoln, Canterbury, New Zealand \\ ${ }^{3}$ Department of Plant Sciences and Institute for Nature Conservation Research, \\ The George S. Wise Faculty of Life Sciences, Tel Aviv University, Tel Aviv 69978, Israel \\ Corresponding author: cards@lincoln.ac.nz
}

Botrytis cinerea Pers is a necrotrophic pathogen that causes grey mould, a most important disease of strawberry, worldwide. Grey mould of strawberry fruit often originates from infection of the flowers at blossoming. The use of chemical and biological agents at this stage has been demonstrated to considerably reduce the disease. A bioassay was developed to evaluate New Zealand Gliocladium isolates for biocontrol of B. cinerea on detached strawberry flowers. Spore suspensions of the antagonists were sprayed onto field produced flowers and then challenge inoculated with the pathogen. The flowers were then suspended within a humidity chamber at $18-20^{\circ} \mathrm{C}$ for 7 days. All test isolates significantly $(\mathrm{P}<0.05)$ reduced numbers of $B$. cinerea conidiophores with suppression ranging from $83-100 \%$. This bioassay has been shown to be a useful aid in selecting potential biocontrol agents of $B$. cinerea in strawberry and has also identified the genus Gliocladium as a source of powerful biocontrol strains. 